\title{
実構造物の非接触スキャニング 振動計測システムの開発
}

\author{
貝戸清之 ${ }^{1} \cdot$ 阿部雅人 ${ }^{2} \cdot$ 藤野陽三 $^{3} \cdot$ 本村均 $^{4}$ \\ ${ }^{1}$ 正会員 博士(工学) コロンビア大学客員研究員 土木工学専攻 (500 West 120th Street, New York, NY 10027) \\ (研究当時 東京大学大学院博士課程) \\ ${ }^{2}$ 正会員 Ph.D 東京大学助教授 大学院工学系研究科社会基盤工学専攻（ $\bar{T} 113-8656$ 東京都文京区本郷 7-3-1） \\ ${ }^{3}$ フェロー会員 Ph.D 東京大学教授 大学院工学系研究科社会基盤工学専攻 (同上) \\ ${ }^{4}$ 正会員 日本道路公団試験研究所保全研究室室長（ $\bar{T} 194-8508$ 東京都町田市忠生 1-4-1）
}

\begin{abstract}
著者らはこれまで，構造物の振動モニタリングの合理化を視野に入れ，レーザードップラ速度計を用いた非 接触スキャニング振動計測システムを室内実験において構築してきた，しかし，実構造物の振動計測では計測 対象がレーザー反射率の低いコンクリートや污れの付着した鋼材となることが多く，レーザードップラ速度計 の適用には克服すべき課題がある. そこで本研究では, レーザ一戻り光量が計測対象の表面状態に依存すると いう問題を計測点ごとに戻り光量が最大となる点を自動探索することで解決し，システムの改良を行った。 こ れにより実構造物を対象とした際の計測精度の大幅な改善を図った。一例として，実橋の鋼析および RC 床版 の振動計測を行い, 計測精度を実証するとともに部材固有の部分振動モード形の同定を可能とした.
\end{abstract}

Key Words: laser doppler vibrometer, non-contact \& scanning vibration measurement, identification, mode shape, steel girder, reinforced concrete deck

\section{1. はじめに}

構造物のモニタリングは, 理論モデルと実計測データと をつなぐ媒体としての役割を期待されている. 実際に, 構造物の性能評価, 損傷同定, 精緻な構造モデルの構筑 および維持管理を目的として，振動という手段を用いた モニタリングが盛んに行われるようになってきた ${ }^{1,2)}$. これは，近年のセンサー計測精度やコンピュータ技術の 飛躍的な発展に加え, 振動特性に対する様々な同定手法 が体系化されつつあることが背景にある ${ }^{3)}$.

このような状況のなかで, より詳細な振動情報, 例えば 高振動数成分の振動特性や, さらに固有振動数や減衰比 といった情報に加えて空間情報である振動モード形を把 握したいという要望が高まっている，実際に，損傷同定 では, 高次の振動モード形が初期の局所的な損傷検出に 有効であると報告されている ${ }^{4)}$ 。しかし, 現状の振動乇 ニタリングで用いられるセンサーは，接触型の加速度計 が主流であり, 高次の振動モード形を得ることは極めて 難しい. その理由としては, センサーの高振動数領域に
おける精度不足のみならず, センサ一数が増加すること による設置作業の負担が増すことがあげられる.これは， 構造物が大型になるほど, 無視できなくなる問題であり, センサーとしては非接触かつ多点計測が可能なものを使 用することが望ましいところである.

さらに, 振動計測における作業の効率を考えると, 入力 としては供用状態における常時微動を用いることが望ま しい. しかし，常時微動は，その要因が多岐にわたるた めにそれ自身の計測が難しく，非定常であるのに加え， 振動振幅が微小である. そのため，用いるセンサーは， 微小振動を高振動数成分まで高精度に計測することが可 能なものでなければならない.

これまでに著者らは, これらの問題点を解決し得るセン サーとしてレーザードップラ速度計に着目し, 非接触ス キャニング振動計測システムを構築してきた. さらに, 常時微動計測に対する実用性と信頼性の向上を図りつつ, その計測結果に基づいた振動モード形の同定手法につい

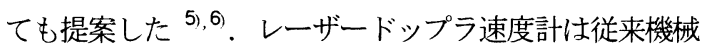
振動の分野 ${ }^{7 ， 8)}$ での適用が主流で, 計測対象の加振が容 


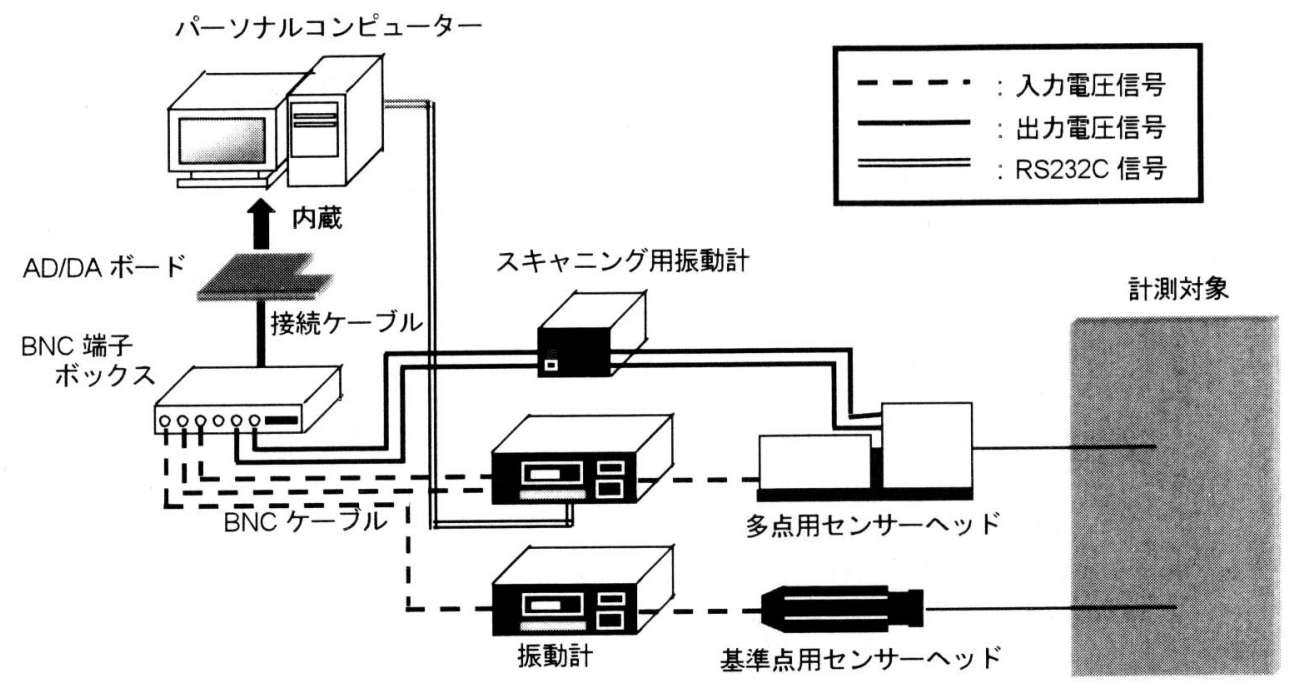

図-1 レーザードッブラ速度計を用いた非接触スキャニング振動計測システム

易かつ加振力の計測が可能であったために，確立され たモード解析を用いることができた。これに対し，著 者らの研究は, 未知の常時微動入力作用下において振 動モード形の同定を実現しており，実構造物一の適用 という見地からすると一歩進んだものであると考えて いる. しかし，実験はノイズレベルが低い室内で，レ 一ザー反射率の高い鋼板を対象として実施されたもの であったので，実用化に際しては未知の面が多分にあ った. なかでも，実構造物では，振動計測の対象は污 れが付着したコンクリート部材や塗装された鋼材であ り，レーザー反射率の低下によって計測精度が大幅に 低下することが問題となると予想された. 通常レーザ 一反射率が低い場合には計測対象に対して反射テープ 等による表面処理を行うが，実構造物ではそれらによ る解決は非接触計測の利点を損なうことになる.

以上を踏まえ, 本研究では実構造物の振動計測に対 して適用が可能な非接触スキャニング振動計測システ ムを開発することを目的とする.

そのために, システムのハードウェア面に関して, レーザー戻り光量が不足して計測精度が低下する計測 点に対しては，その計測点周辺でレーザー戻り光量の 計測を行い, 戻り光量が最大となる点を自動的に探索 する機能を追加することで計測精度の改善を図る. 一 方, ソフトウェア面に関しては, 戻り光量不足に起因 する光学ノイズの判定基準を新たに設けることとする。 実構造物の振動計測の実例として, 鋼析および RC 床 版の走行荷重作用下においてスキャニング振動計測を 実施した. 計測精度を実証した後, 非定常かつランダ ムな振動データから部材固有の部分振動モード形を同 定することを可能とした.
表-1 レーザードップラ速度計性能諸元

\begin{tabular}{|c|c|}
\hline レーザータイプ & $\mathrm{He}-\mathrm{Ne}$ レーザー \\
\hline 波長 & $633 \mathrm{~nm}$ \\
\hline レーザー出カノクラス & $2.3 \mathrm{~mW} / \mathrm{III} a$ \\
\hline 計測可能距離 & $\sim 100 \mathrm{~m}$ \\
\hline 分解能 & $0.5 \mu \mathrm{m} / \mathrm{s}$ \\
\hline 計測可能周波数帯域 & $0 \mathrm{~Hz} \sim 35 \mathrm{kHz}$ \\
\hline レーザー照射角 & $-15 \sim 15$ 度 \\
\hline
\end{tabular}

\section{2.レ一ザー反射率の低い部材を対象とした非接 触スキャニング振動計測システムの構築}
（1）レーザードップラ速度計と非接触スキャニング システムの概要

レーザードップラ速度計は，レーザー光を移動物体 に照射し，その照射光と反射光との位相差 $\Delta \theta$ から下 式を用いて速度を検出する光学式干渉計である.

$$
\Delta \theta=\frac{4 \pi t}{\lambda} V
$$

式中， $t$ は時間， $V$ は移動物体の速度， $\lambda$ はレーザー光 の波長をそれぞれ表す.

非接触スキャニング振動計測は，レーザードップラ 速度計のセンサー内部に取りつけた 2 枚の反射鏡を自 動制御することにより行う ${ }^{5}$ 。構筑したシステムの概 要を図-1に示す，パーソナルコンピュータでは，計測 時間や計測点数等の条件の入力から, 反射鏡の制御, データの取りこみおよび計測結果のリアルタイム表示 までを一括して管理・実施する。 なお，本研究で用い たレーザードップラ速度計の性能諸元を表-1 に示す. 


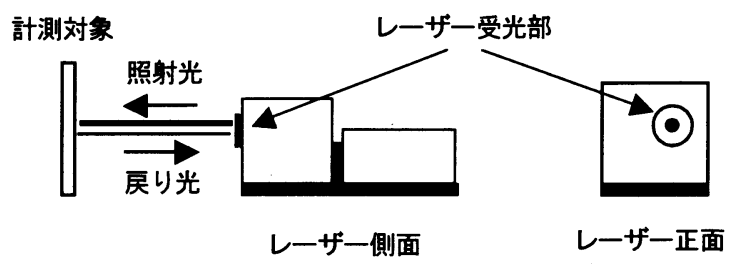

(a) 鏡面反射

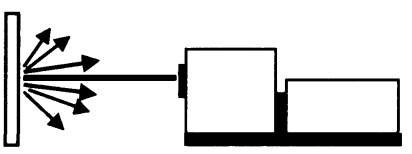

(b)乱反射

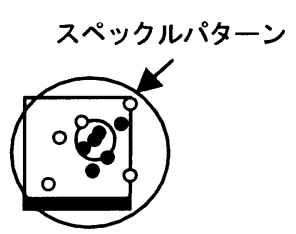

(c)スペックルノイズの発生原理
I

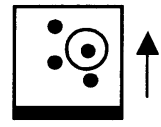

II

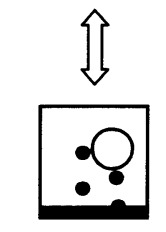

図-2 受光漏れに起因する光学ノイズの発生原理

実橋における振動計測を想定すると，(1)コンクリー トや污れた鋼部材が計測対象で, かつ計測距離が長く, レーザー照射角が大きくなるのでレーザー戻り光量が 低下寸る，(2)周辺環境のノイズレベルが高くなる，(3) 走行荷重が作用するために振動計測結果は非定常性が 強く, 振動モード形の同定が困難となるといった問題 が生じてくる.

周辺環境のノイズに関する主たる問題は，レーザー ドップラ速度計自身が振動することである。これにつ いてはセンサーの防振対策，さらにはセンサーの振動 を別のセンサーによって計測してレーザードップラ速 度計により計測された時系列からこれを減算すること で対処することができる.

また，文献 6)では，強い非定常性を有する振動計測 結果に基づく振動モード形の同定に関しては, 基準点 計測用のレーザードップラ速度計を追加することで対 処し，実際に衝撃加振入力時の振動計測結果から振動 モード形の同定を実現している.

レーザー戻り光量の低下に関しては，それによって 生ずる光学ノイズの混入が少なければ, フィルタ等に よる信号処理で除去することができる.しかし，計測 が不可能となるレベルの光学ノイズが混入する場合に はハードウェアやソフトウェアに新たな改良が必要と なる。これらについては, 次節以降で詳細に述べる.

\section{（2）レーザー戻り光量最大点の自動探索}

振動計測が不可能となる不良計測点では，レーザー 戻り光量不足により, 光学ノイズが数多く生じている. この戻り光量不足の要因としては，以下の 5 つがあげ られる。レーザードップラ速度計自身に関しては, (1)
レーザー出力の安定性があげられる. 計測対象に関し ては，レーザーに対する(2)低反射特性，または(3)乱反 射特性があげられる. 計測条件に関しては, (4)計測距 離，(5)レーザー照射角度があげられる.

(1)と(2)では，図-2(a)に示すようにたとえ鏡面反射す るものを対象とした場合であっても受光部で検出され る戻り光量が直接低下することになるために, 光学) イズが発生する. (3)では, 図-2(b)に示すように乱反射 することで戻り光量が分散されるために, 受光部で検 出される戻り光量が少なくなる. このときの戻り光量 の分散の様子はスペックルパターンと呼ばれている. これに(4), (5)の条件が加わると, さらに受光部におい て受光できる戻り光量が減少する. これらは受光漏れ に起因する光学ノイズである. その計測例を図-3(a) に示す.

一方，図-3(b)に見られるようなスパイク状のスペッ クルノイズが発生することもある.このノイズも受光 漏れに起因する光学ノイズの一種であり, 発生原理は 以下のとおりである. 図-2(c)のI の状態にあったスぺ ックルパターンがセンサー自体の振動, または計測対 象のレーザー照射方向以外一の振動により，例えば同 図中の矢印の方向に一瞬移動する．そうすると，IIの ように受光部で検出できる戻り光がない状態となって しまい，受光漏れが生ずる. しかし，先のノイズとは 異なり，この状態は瞬間的に起こるためにノイズはス パイク状となって現れる。

実構造物へのレーザードップラ速度計の適用は，こ の光学ノイズを如何に低减し，さらに取り除くかが重 要となる. (1)につては, 計測を開始するまでに十分 なウォーミングアップの時間を取ることである程度の 


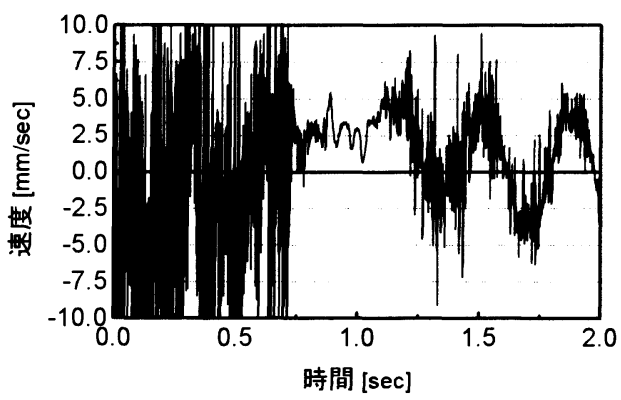

(a) 受光漏れによるノイズ

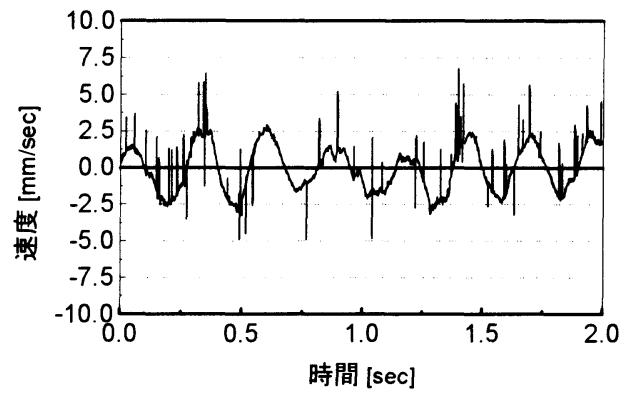

(b) スペックルノイズ

図-3 受光漏孔によるノイズの計測例

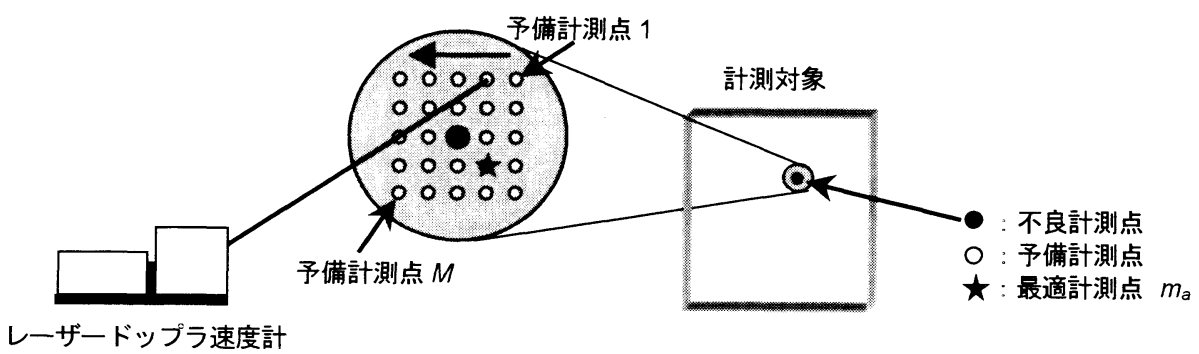

図-4 レーザー戻り光量最大点の自動探索

改善が可能である. また，本器はレーザー出力を通常 の $1[\mathrm{~mW}]$ から $2[\mathrm{~mW}]$ に改良しており, 出力が低下寸 る場合に対しても対処している. ただし，これ以上出 力を高めると, レーザ一使用時に保護メガネの着用や 使用届の提出といった法的制限がかかるために, 屋外 での計測が困難となる. (4), (5)については, 変更を施 すと実構造物の非接触スキャニング計測の利点を損な うことになってしまう. したがって，(2)，(3)にいて 改善を図ることが計測精度の向上につながる.

著者らは，これまでに計測対象の反射特性や乱反射 特性がその表面状態に大きく依存し，レーザ一照射点 を微妙に変化するだけでも戻り光量が全く異なること を経験している，そこで，不良計測点に対しては，こ の特性を逆に利用し, その計測点周辺で相対的にレー ザー戻り光量が最大となる計測点を探索して新たな計 測点として置き換え，計測精度の向上を図ることとし $た^{10}$.

具体的には，不良計測点に対しては，その計測点近 傍の数点（これを予備計測点と乎ぶ）について，それ ぞれレーザー戻り光量の時系列を計測する. その概念 を図-4に示す. 戻り光量は, 振動計内部で電圧值に変 換し，その電圧值を図-1 のように入力 $2 \mathrm{ch}$ から $\mathrm{AD}$ コ ンバータを通してパーソナルコンピュータに時系列と して保存する. 予備計測点ごとに計測される戻り光量
の時系列からその平均值を算定する. 例えば, $i$ 番目の 予備計測点における平均值 $\bar{x}_{i}$ は, 次式で与えられる.

$$
\bar{x}_{i}=\frac{1}{N} \sum_{k=1}^{N} x_{i}(k) \quad(i=1,2, \ldots, M)
$$

式中, $N$ は総データ数, $M$ は総予備計測点数を表す. 次に, 全ての計測点の中から最大平均値 $\bar{x}_{a}$ を与える点 を最適計測点 $m_{a}$ として選定し, 新たな計測点と設定す 万.

$$
\bar{x}_{a}=\max \left(\bar{x}_{1}, \bar{x}_{2}, \cdots, \bar{x}_{M}\right) \quad(1 \leq a \leq M)
$$

これより，実構造物に対しても反射テープ等の表面 処理をすることなしに，レーザードップラ速度計によ る非接触計測が可能となる，ただし，レーザー出力の 安定性などを考えると, 選定された最適計測点 $m_{a}$ が常 に計測に十分な戻り光量を与え得るとは限らない. そ こで, 光学ノイズに対する判定基準を定め, 規準を満 たす振動計測結果が得られるまで $m_{a}$ での計測を繰り 返すこととした. ノイズの判定基準については次に述 べる.

\section{（3）受光漏れによる光学ノイズの判定基準}

ソフトウェア部においては，不良計測点の決定，す なわち受光漏れによる光学ノイズの判定が計測精度の 
向上のために重要となる. 参考文献 11)では, このノイ ズの判定は，設定した基準值を超える值が振動計測結 果中に存在するかどうかによって行っている. しかし， 走行荷重のような非定常入力が作用する場合には, 振 動計測ごとに振幅が異なるために基準值を設けること はできない，そこで，以下のような 2 段階のデー夕処 理を行うこととする.

第一段階は，図-3(a)に見られるようなノイズを含む 振動計測結果の除去を目的とする. 本器は, 速度信号 を土10[V]の範囲で電気信号に変換し, 収録している. 具体的には図-3(a)の場合, 用いた速度レンジは $1[\mathrm{~mm} / \mathrm{sec} / \mathrm{V}]$ であるので, このときの最大速度は $10[\mathrm{~mm} / \mathrm{sec}]$ となる. 実際に, 受光漏孔によるノイズは この最大值を超えていることから, 最大値をしきい值 にしてノイズを判定することができると考え, その振 動計測結果を収録しないものと定める. そのために, 新たにパーソナルコンピュータのシリアルポートから RS232 ケーブルを通して最大速度を超えるデータの有 無を計測時に確認する，振動計測システムは，図-1に 示したとおりである. シリアルポートからコマンド $O I R$ を送信する. OIR は最大電圧值を超える入力を検 出するコマンドで, この場合には速度時系列 $v(t)$ が最 大速度 $R$ を超える場合には 1 ，超えない場合には 0 を 返すとした。

$$
\begin{aligned}
& v(t) \leq R \rightarrow O I R=0 \\
& v(t)>R \rightarrow O I R=1
\end{aligned}
$$

最終的に, 振動計測結果中に $O I R=1$ を有するものにつ いては収録しないこととする.

第二段階では，最大速度を超えないスペックルノイ ズに対する処理を行う. スペックルノイズは図-3(b)に 示すように最大速度を超えないことも多く，第一段階 の判定によって除去しようとすると，健全なデータも 除去されることになり，不必要に計測時間を費やして しまう. そこで, この種のノイズに対しては, 同一点 での振動計測を繰り返し, 振動数領域で速度振幅スペ

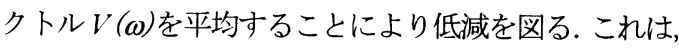

$$
\bar{V}\left(\omega_{j}\right)=\frac{1}{N_{A}} \sum_{k=1}^{N_{A}} V_{k}\left(\omega_{j}\right)
$$

として表すことができる. 式中, $\bar{V}(\omega)$ は速度振幅スペ クトルの平均值, $N_{A}$ は繰り返し計測回数である. $N_{A}$ ついては 4. (4) 節で統計的判断による決定手法を述べ る. 著者らは, 参考文献 6) で振動数領域における固有 振動数と振動モード形の同定手法を提案しており, 式 (6)の速度振幅スペクトルの平均值をそこに適用する ことで，スペックルノイズの影響を除去した状態で同 定を行うことが可能となる.

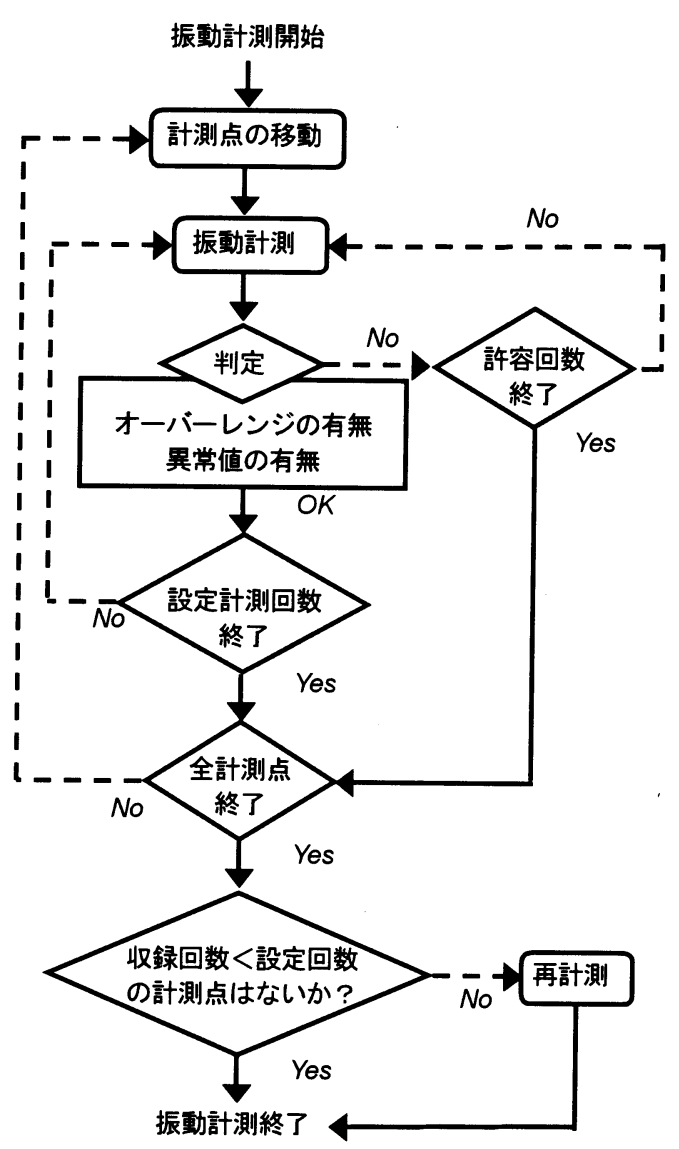

図-5 振動計測アルゴリズム

\section{(4) 振動計測の流れおよび振動モード形の同定手法}

以上の手法を組み込んだ振動計測の流れを図-5 に示 す. 設定した数の計測点に対して，先述したスペック ルノイズレベルの低下を目的とする平均に必要な計測 回数 $N_{A}$ だけ計測点ごとの振動計測を実施する. これら の時系列に対して, 提案したノイズ判定手法に基づい て振動計測結果の良し悪しを判断する.

このとき, 繰り返し計測回数とは別に計測許容回数 $N_{R}$ 設定し，これを超える計測点については，その時 点で一時計測を打ち切り，再計測を行う。再計測では 不良計測点ごとにレーザー戻り光量の最大となる最適 計測点を自動探索し, 繰り返し計測回数に達するまで 振動計測を行う.

振動モード形の同定では，常時微動のような非定常 入力を対象とすること，レーザードップラ速度計は多 点同時計測が不可能であることから，基準点計測用の レーザードップラ速度計を 1 基追加した. 多点計測用 および基準点用レーザードップラ速度計のそれぞれの 速度振幅スペクトルの平均值からクロススペクトルの 
表-2 加速度計性能諸元

\begin{tabular}{|c|c|}
\hline 分解能 & $0.00001 \mathrm{~m} / \mathrm{sec}^{2}$ \\
\hline 最大計測可能加速度 & $0.1 \mathrm{~m} / \mathrm{sec}^{2}$ \\
\hline 応答周波数 & $0.1 \sim 100 \mathrm{~Hz}$ \\
\hline 最大サンプリング周波数 & $1000 \mathrm{~Hz}$ \\
\hline 入カ電圧 & $\pm 10 \mathrm{~V}$ \\
\hline
\end{tabular}

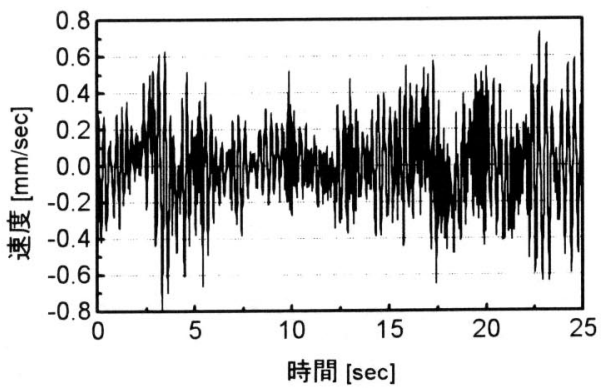

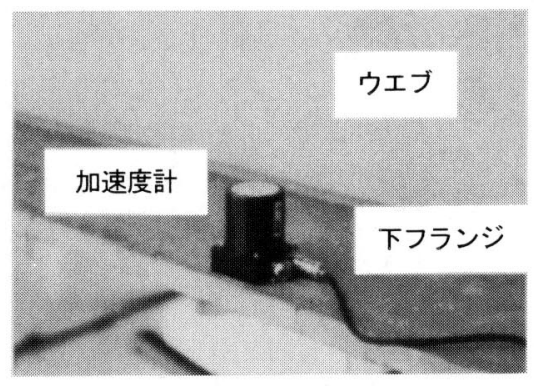

図-6 加速度計設置状況

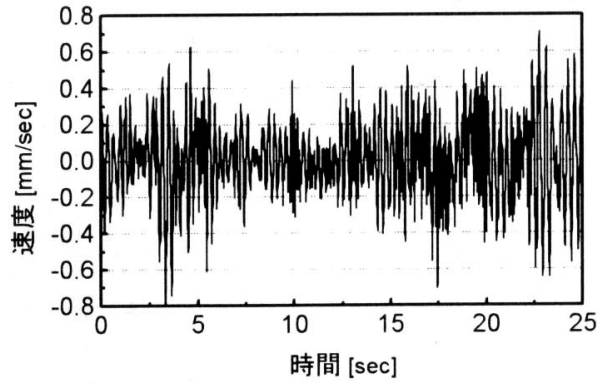

(a) 時系列比較（左 : レーザードップラ速度計, 右 : サーボ型加速度計)
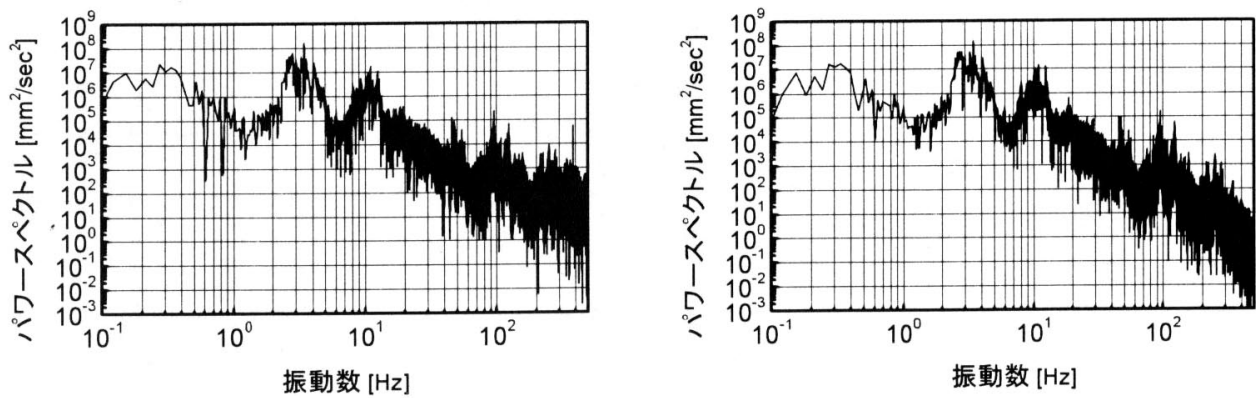

(b) パワースペクトル比較（左 : レーザードッブラ速度計, 右 : サーボ型加速度計）

図-7 レーザードップラ速度計の計測精度検証

平均值 $X_{k r e f}(\omega)$ を求め, そのピーク振動数から固有振動 数を同定する.ささらに，このクロススペクトルの平均 值を出力，基準点でのパワースペクトル $\left.\mathrm{A}_{r e f}(\omega)\right|^{2}$ を入 力として計測点ごとに次式で表される伝達関数 $T_{k}(\omega)$ を算出する.

$$
T_{k}(\omega)=\frac{X_{k r e f}(\omega)}{\left|X_{r e f}(\omega)\right|^{2}}
$$

このとき, 固有振動数に対応する伝達関数の振幅加ら 振動モード振幅を，位相からモードの位相を決定する. なお，同定理論の詳細については，参考文献6）を参照 されたい.

\section{3. 鋼析振動計測}

\section{(1)橋梁および実験の概要}

対象とした A 橋梁は 5 主桁, RC 床版を有する高架橋 である、レーザー振動計測は鋼析を対象として実施し， その部材固有の振動モード形を同定することを目的と した.レーザードッブラ速度計は, 鋼析から約 $11.5[\mathrm{~m}]$ 離れた地上に設置した。橋は供用状態であったので入 力は実交通荷重となる. 


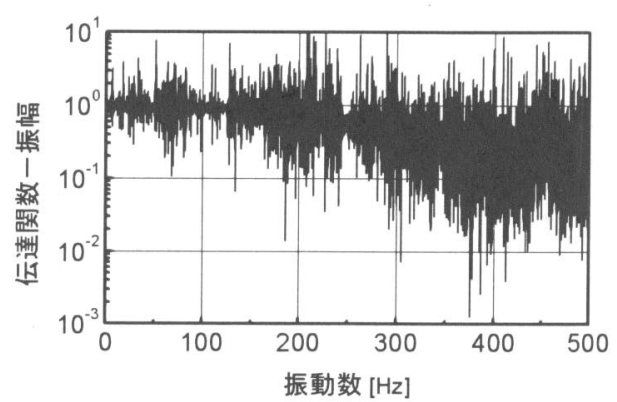

図-8 伝達関数による計測精度検証

\section{(2) 計測精度の検証}

レーザードップラ速度計の計測精度を検証するため に，鋼桁下フランジ上にサーボ型加速度計（性能諸元 は表-2 に記載）を設置し，常時微動を入力とした時の 応答を比較した。サーボ型の加速度計の設置状況は図 一に示すとおりである. 一方，レーザー光は加速度計 設置点と同一点に桁下から照射した。レーザードップ ラ速度計は多点計測用を用いた。計測条件はともにサ ンプリング周波数 $500[\mathrm{~Hz}] ，$ サンプリング個数 12500 個で，計測時間は $25[\mathrm{sec}]$ とした。 また，地盤振動によ ってレーザードップラ速度計自身が振動することを防 止するために，防振ゴム上にセンサーを配置した．ち なみに，レーザードップラ速度計の設置箇所での地盤 振動を計測したが，桁の振動と比較すると，標準偏差 で約 0.05 倍程度と小さいことを確認した。したがって, 地盤振動の影響は小さいと考え，センサーに対しては 防振ゴムによる処理以外は行っていない.

常時微動入力に対するそれぞれの振動計測結果を図 -7(a)，パワースペクトルを図-7 (b)に示す。ただし， 加速度計により計測した加速度応答は, 速度応答を数 值積分した．応答は時間領域，振動数領域のいずれに おいても高い整合性を確認できる．その傾向は図-8の ように，レーザードップラ速度計による速度応答を入 力, 加速度計による加速度応答を先と同様に積分して 得た速度応答を出力として, 式(7)から求めた伝達関数

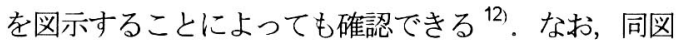
において 200[Hz]から整合性は低下しているが，これ は用いた加速度計の応答特性が $100[\mathrm{~Hz}]$ から徐々に低 下していることによる. 以上により，レーザードップ ラ速度計を用いた非接触振動計測は実橋においても可 能であると判断した。

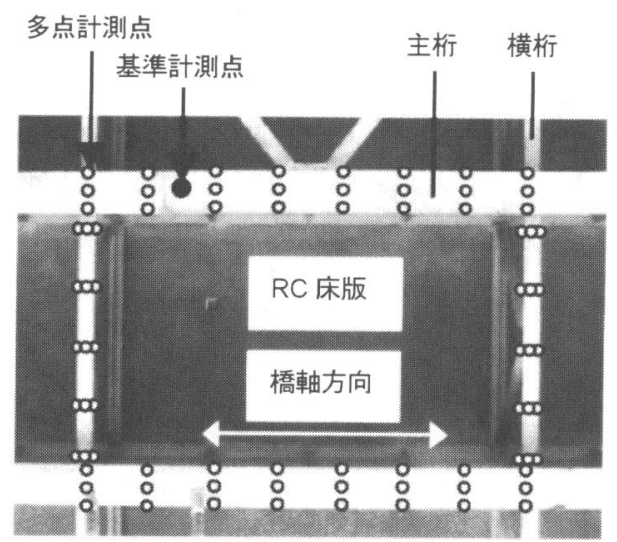

図-9 鋼桁計測点

\section{(3) 鋼桁の振動モード形の同定}

鋼析の振動モード形を同定することを目的として非 接触スキャニング振動計測を実施した。計測点は図-9 に示寸ように，主桁に対しては橋軸方向に 8 点, 橋軸 直角方向に 3 点の計 24 点設け, 横析に対しては橋軸方 向に 3 点, 橋軸直角方向に 5 点の計 15 点設けた. 総計 測点数は，78 点であった．また，基準点に関しては数 回の試行錯誤の後に，同図の○で示した位置に決定し た．各計測点に対寸る計測条件は，サンブリング周波 数を $1000[\mathrm{~Hz}]$ ，サンプリング個数を 2048 個, 計測時 閒を $2.048[\mathrm{sec}]$ とした。 また，平均值の計算に要する 計測回数を 20 回，再計測までの許容回数を 30 回とし た.

多点計測用レーザードップラ速度計による振動計測 結果の一例息図-10 に示す。この計測点におけるレー ザ一照射角は，橋軸方向に 0 度，橋軸直角方向 3 度で あった. 振動計測結果は, 受光漏れによる光学ノイズ が混入していない良好なものであった，実際に，鋼析 の污れの付着はそれほどなく, 再計測を要する不良計 測点はなかった。

図-11 は，基準点における振動計測結果を入力，計測 点 1 における振動計測結果を出力としてクロススペク トルを算出し，それらを20回重祆合わせたクロススペ クトルの平均值である. 通常の振動計測結果から算出 した場合には，最大信号成分とノイズ成分の振幅比で 定義される $\mathrm{S} / \mathrm{N}$ 比 ${ }^{9}$ は $60[\mathrm{~dB}]$ 程度であったが, 平均化 を行うことで $\mathrm{S} / \mathrm{N}$ 比が $70[\mathrm{~dB}]$ に向上した.

2.(4) 節の手順に従って同定された鋼析の振動モード 形は図-12 に示すように 6 モードを同定することを可 能にした. このうち，1 次は桁全体が一体となって振 動する上部構造全体の振動モード形である. 図中の丸 囲み部分の振動が卓越しているが，これはこの付近に 照明灯が設置されており，その支持部材の影響であっ 


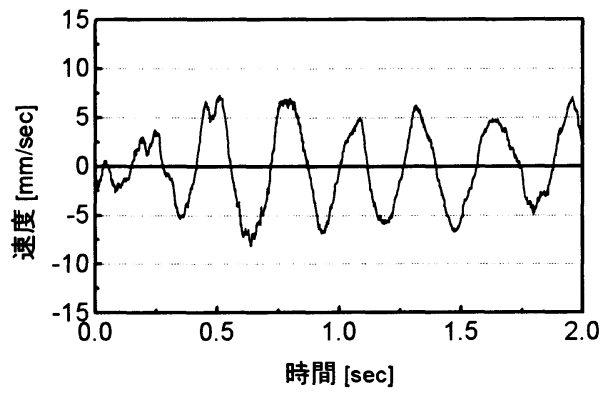

(a) 時采列

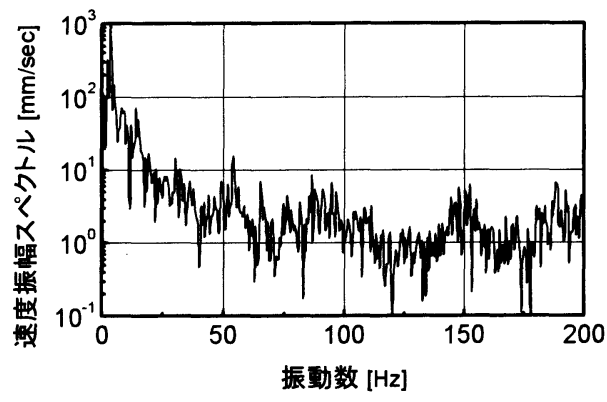

(b) 速度振幅スペクトル

図-10 鋼析の振動計測結果の一例

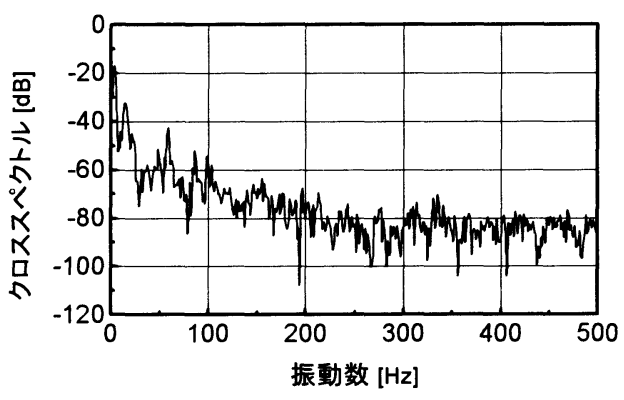

図-11 クロススペクトルの平均值

たと考えられる. 実際に 2 次モードでは，その部分の みが卓越して振動している様子が確認でき, その支持 部材の固有振動数が $13[\mathrm{~Hz}]$ 付近にあるものと推察で きる. 3，4，6 次モードは, 図より判断して, いずれ も鋼析の固有のたわみ振動モードであることがわかっ た. 以下，これらのように一部に関する振動モード形 を部分振動モード形と呼び, 上部構造全体のそれと区 別することとする. 5 次モードも部分振動モード形で あるが，とくに横桁のみが単独で振動している局所的 な振動モード形である. 以上より，レーザー常時微動 計測を行うことで, 部材固有の高次振動モード形まで も精度よく同定することが可能である.

なお,ここでは, 同定結果に対して解析結果との比 較を行っていない. これは, 計測対象が局所的なため に, 材料特性の不均一性や境界条件等を精絰にモデル 化する必要があるが，そのような構造モデルを構筑す ることが困難であることによる. ただし, 計測精度に ついては3.(2)節において加速度計との比較から $100 \mathrm{~Hz}$ までの検証を行っている. $100 \mathrm{~Hz}$ 以上の精度に関して は今回直接的には精度検証が行えなかったが, 光学ノ イズが混入していない良好な計測結果であれば, $600 \mathrm{~Hz}$ まで振動モード形の同定が可能であることを参考文献
6)で示しており，今回の振動計測結果および同定結果 も妥当なものであったと考えている.

\section{RC 床版振動計測}

\section{(1) 対象橋梁および実験概要 ${ }^{13)}$}

対象とした B 橋梁は図-13 に示すように, 4 主析, $\mathrm{RC}$ 床版を有する高架橋である. 振動計測は, RC 床版 半パネル (図-13 中の黒塗り) を対象とした. RC 床版 は, コンクリート厚 $17[\mathrm{~cm}] て ゙, ~ 7.5[\mathrm{~cm}]$ のアスファル 卜舗装がなされている. また, RC 床版の表面状態は良 好で, 健全なものと判断された.

レーザードップラ速度計は, $14[\mathrm{~m}]$ 離れた地上に設置 $し$, 計測点数は橋軸方向 9 点, 橋軸直角方向 5 点の計 45 点とした. RC 床版に対する多点計測点および基準 計測点を図-14に示す. 1 点あたりの1回の計測条件は, サンプリング周波数 2048 [Hz] , サンプリング個数 4096 で計測時間を $2[\mathrm{sec}]$ と設定した. 先と同様, 橋は供用 状態にあるので, 入力は走行荷重となる.

\section{(2) RC 床版の振動計測結果}

レーザー照射角が, 橋軸方向に 2 度, 橋軸直角方向 7 度で, ともに今回計測中の最大照射角度であった計測 点 1 における振動計測結果を図-15 (a)に示す.これは, 受光漏れによる光学ノイズが数多く混入した振動計測 結果であり，通常コンクリートを対象としてレーザー 振動計測を行った場合の例である.これに対して, 図 15 (b) はレーザー戻り光量最大点の自動探索後の振動 計測結果である. 最適計測点を決定するに際にしては, 初回の振動計測点周りに 121 点の予備計測点を設け, それぞれについて戻り光量を $0.5[\mathrm{sec}]$ 計測し, その時 系列の平均值を算出した. これより，実際に自動探索 を行うことで, コンクリートに対しても光学ノイズが 混入しない振動計測結果を得ることができる. 


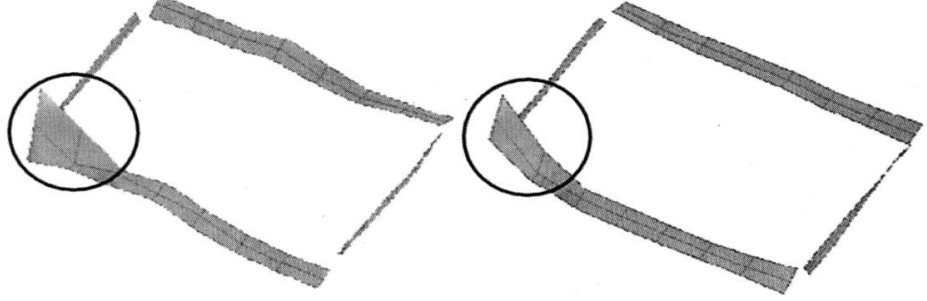

(a) 1 次モード $(3.2 \mathrm{~Hz})$

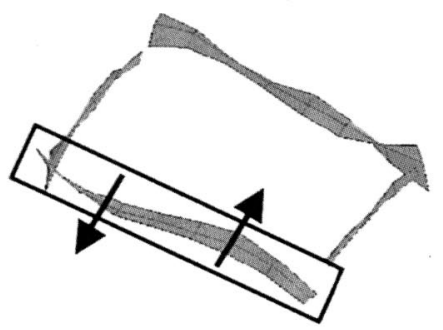

(d) 4 次モード（2 次曲げたわみ，68Hz） (b) 2 次モード $(13.4 \mathrm{~Hz})$

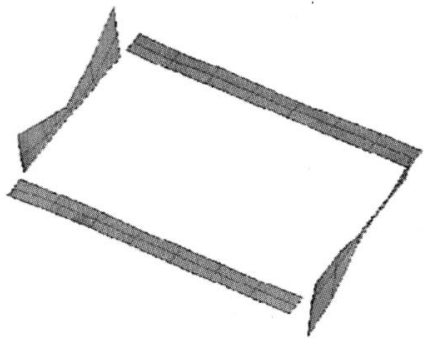

(e) 5 次モード（横桁単独, $133 \mathrm{~Hz}$ )

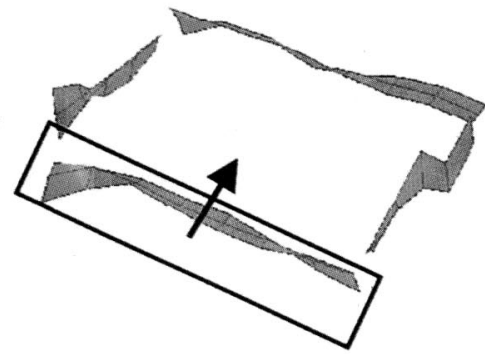

(c) 3 次モード（1 次曲げたわみ，24Hz)

図-12 鋼林の振動モード形

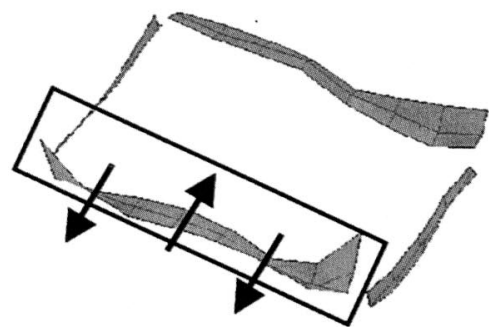

(f) 6 次モード（3 次曲げたわみ，153 Hz）

振動計測位置
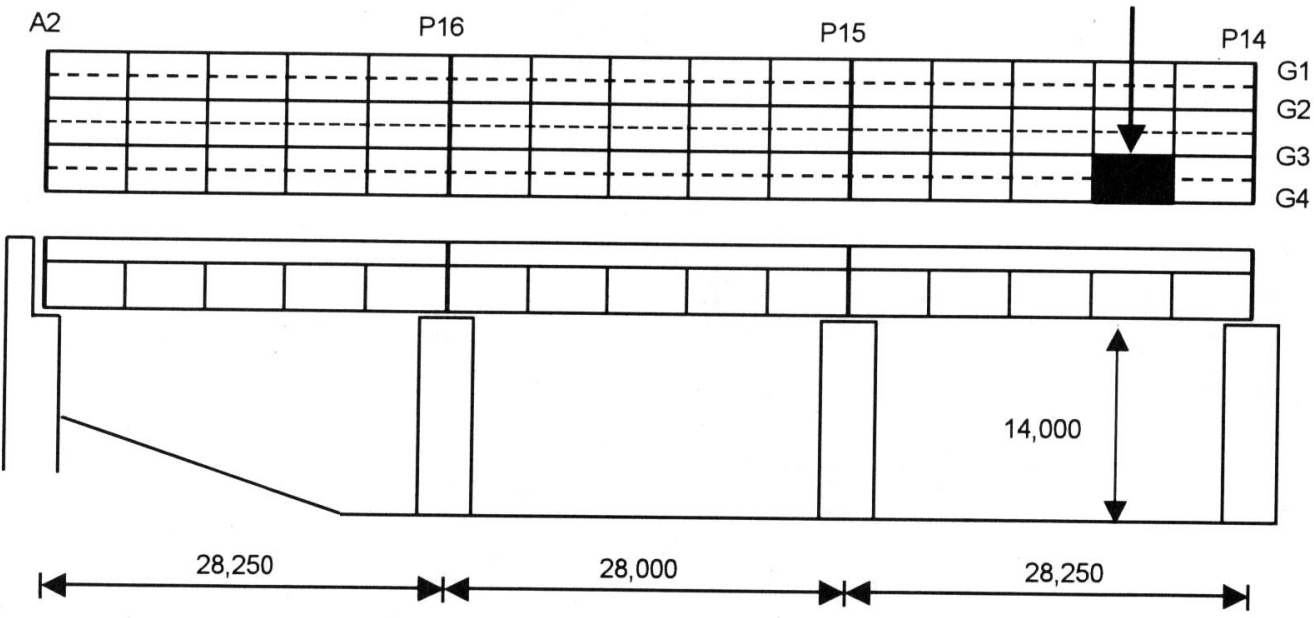

図-13 B 橋梁上面よび側面（単位 $\mathrm{mm}$ ）

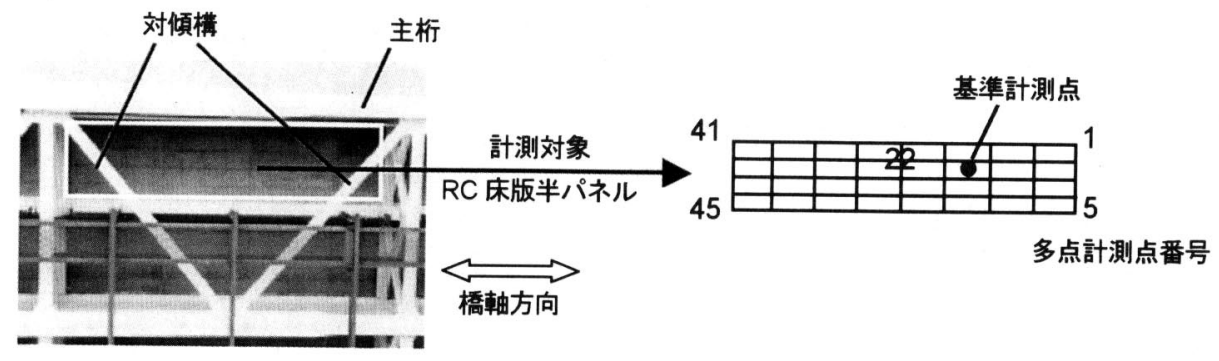

図-14 RC 床版および計測点 


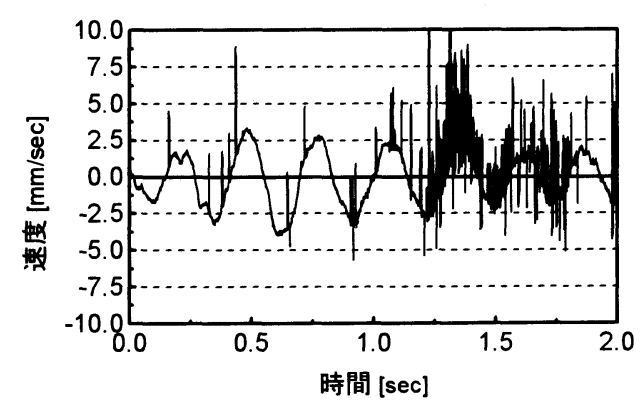

(a) 自動探索前

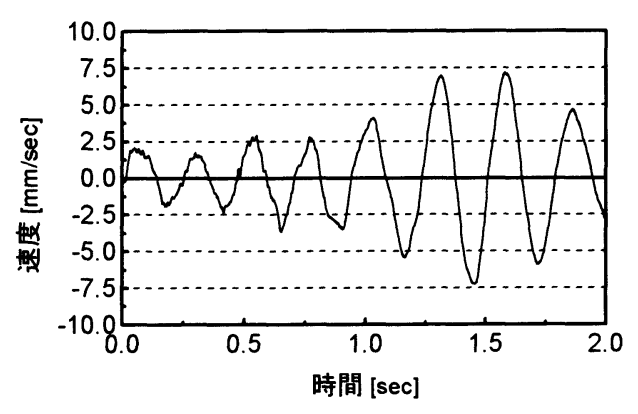

(b) 自動探索後

図-15 RC 床版の振動計測結果の一例（計測点 : 1）

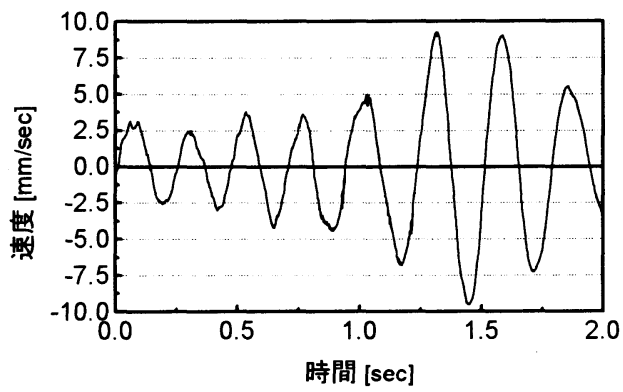

(a) 時系列（基準点）

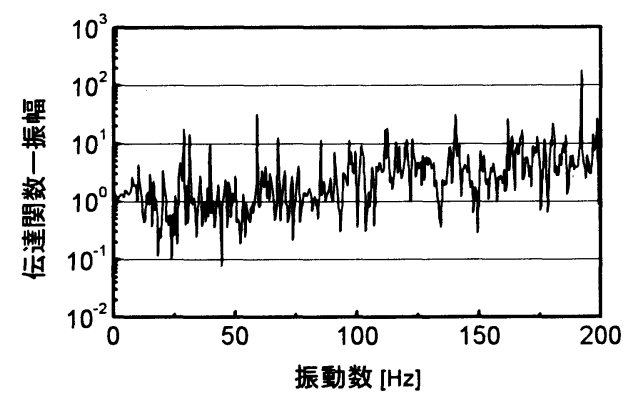

(c) 伝達関数 一振幅一

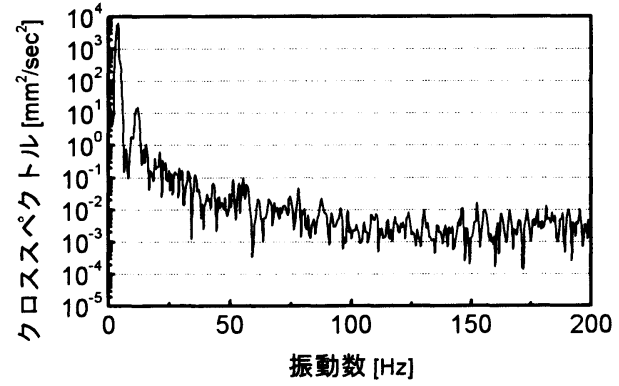

(b) クロススペクトル

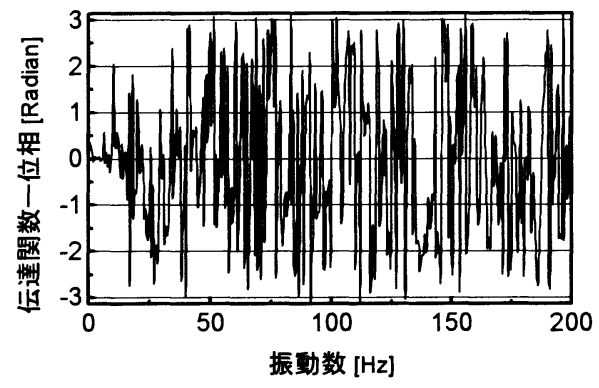

(d) 伝達関数 一位相一

図-16 RC 床版の振動計測結果, クロススペクトルおよび伝達関数

自動探索の結果, 図-15(b)では, 走行荷重による応答 の非定常性も確認することができる. また，この図 -15 (b) と図-16 (a) に示す基準点計測用の振動計測結 果を比較すると, 両計測点が離れているにもかかわら ず，振幅等の特性はほぼ一致している.これより， RC 床版の振動成分は, 床版全体が一体に動く, 上部構造 全体の振動成分が卓越していると考えられる.

今回の振動計測では，全ての計測点で再計測を行っ た. 図-17 には, 各計測点において行った再計測回数 を示す. 図は, 計測点ごとに, 平均に必要な 20 回の繰
り返し計測のうちの自動探索を行わない通常計測とそ れを行う再計測の割合を示したものである.ただし， 計測点 2,9,38,45 においては，対傾向と計測点が重な ったために，振動計測を行うことができなかった。レ ーザー照射角が計測点 22 を中心として大きくなって いるが，レーザー照射角と再計測回数, すなわち光学 ノイズの混入量との間には相関が見られない.したが って，コンクリート部材では，レーザー照射角が計測 精度に及ぼす影響は小さく，むしろその表面状態に大 きく依存することが確認できる. 


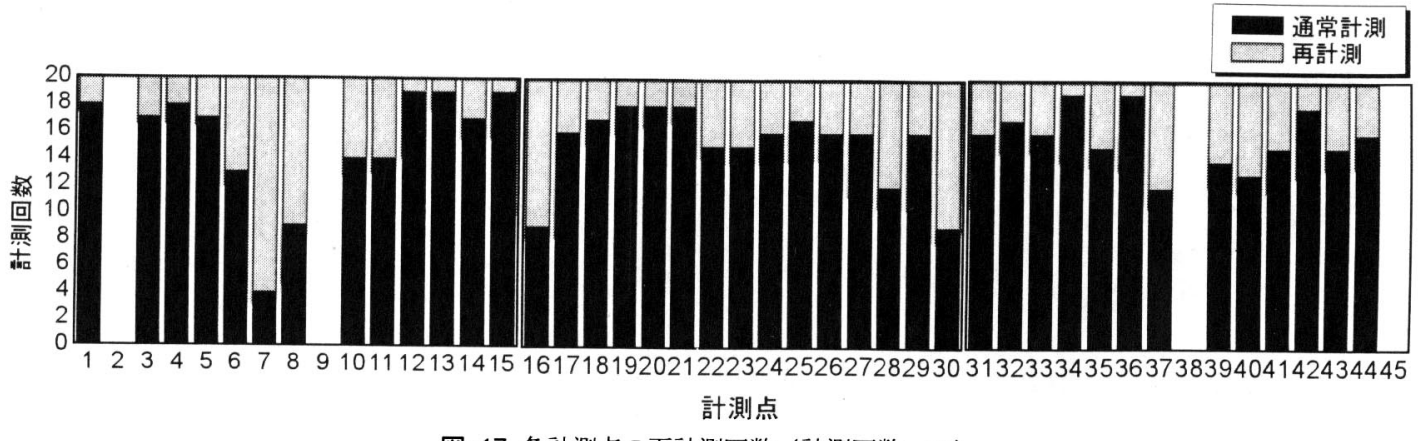

図-17 各計測点の再計測回数（計測回数 : 20)

\section{(3) RC 床版の振動モード形の同定}

図-16 (b) (c) (d) は, 計測点 1 でのクロススペクトル, 伝達関数の振幅と位相である. 図-18 に同一点におい て20 回の平均を行ったクロススペクトルと伝達関数 の平均值を示寸. 平均の回数に関しては, 次節で提案 する統計的手法に基づいて決定した，なお，位相は絶 対值を取った.これらと図-16を比較すると，式(6) と 同様の平均值を計算することでノイズレベルが低下し ている:

図-19 は, レーザー常時微動計測結果を用いて同定し た RC 床版の部分振動モード形である.この際, 計測 が不可能であった 2, 9,38,45 については, 各々周りの 3 もしくは 4 計測点におけるモード振幅の平均值で補間 した. 今回の振動計測では，3 次までのたわみ振動モ ード形について同定することができた。これは，走行 荷重による衝撃的入力が作用して，低い振動数の大振 幅の振動が励起された，つまり低次の振動モード形が 高次より励起されやすくなったためである. さらに高 次の振動モード形を同定するには，ハードウェア面に 関しては, 手動で調節しているレーザースポット径の 照準を計測点ごとに自動調節し, 精度を向上させるこ と, また, ソフトウェア面に関しては, 光学ノイズ判 定基準を強化して $\mathrm{S} / \mathrm{N}$ 比の改善を図り, 高次の微小ピ ークを検出する必要があろう.

この点に関して一例を上げると, 現在のノイズ判定 基準では図-20 のようなオーバーレンジに満たない光 学ノイズを含む振動計測結果は収録されることになる. 振動計測結果の振幅は小さいが, 図-20(b)のようにパ ワースペクトルの $\mathrm{S} / \mathrm{N}$ 比は悪く, 同定精度を低下させ る要因となっている. したがって, 振幅の変動する非 定常振動に対しては, 時間領域のみでノイズ判定を行 うことには限界があり， S/N 比やスペクトル形状に対 しても判定基準を置くことが必要となると考えられる. その場合にも, 当然ながら振動計測ごとに S/N 比の許 容範囲が異なるために，今後，学習機能を備えた人工 知能アルゴリズム等を組み込み, 精度を向上させるこ とが重要であると考えている.

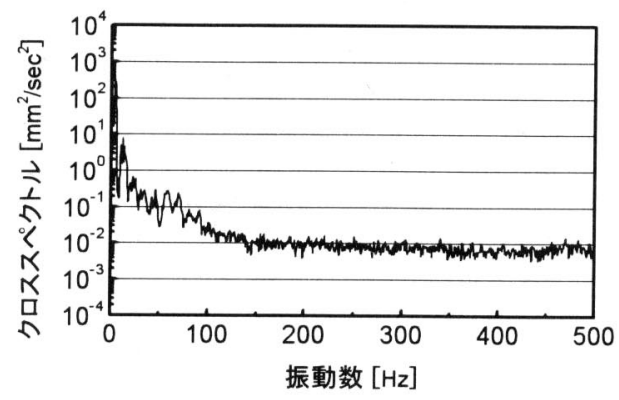

(a)クロススペクトルの平均值

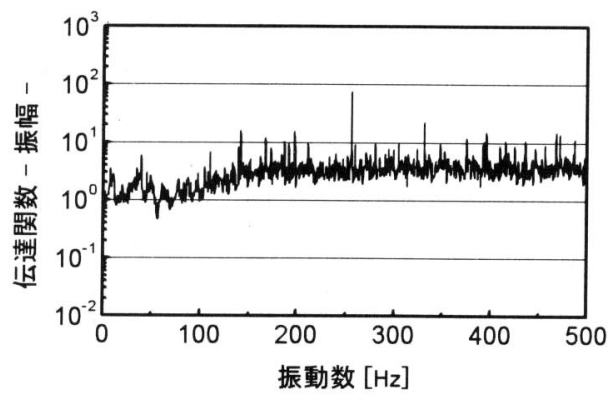

(b) 伝達関数（振幅）の平均値

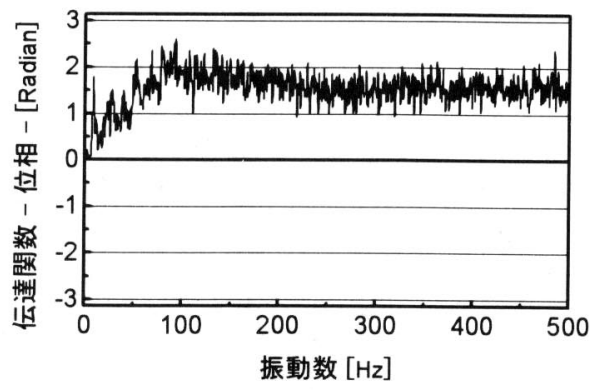

（c）伝達関数（位相）の平均值

図-18クロススペクトルと伝達関数の平均值 （計測回数 : 20 回） 


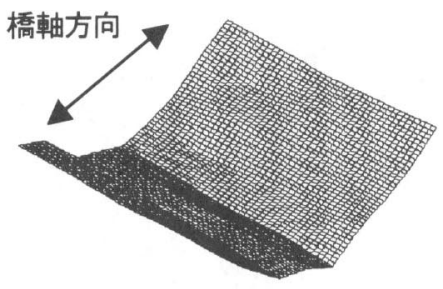

(a) 1 次たわみモード $(43.2 \mathrm{~Hz})$

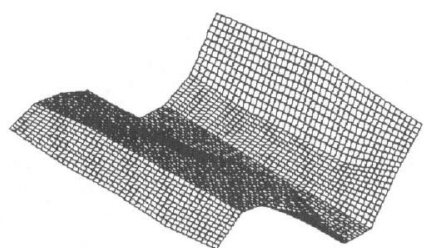

(b) 2 次たわみモード $(97.3 \mathrm{~Hz})$

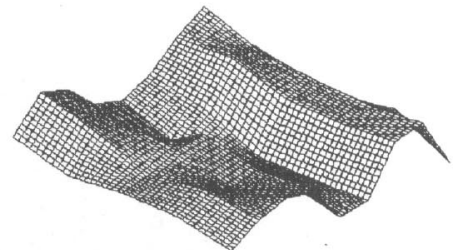

(c) 3 次たわみモード $(187 \mathrm{~Hz})$

図-19 同定された RC 床版の部分振動モード形

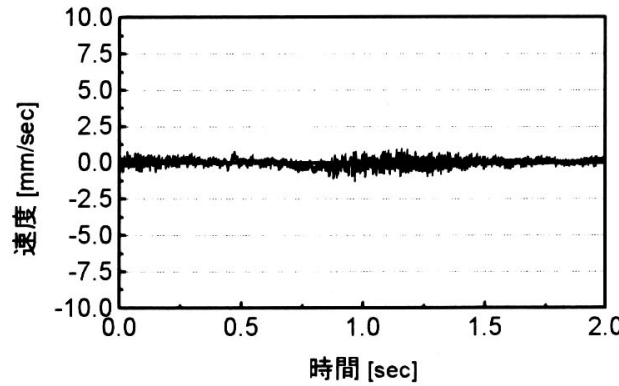

(a) 時系列

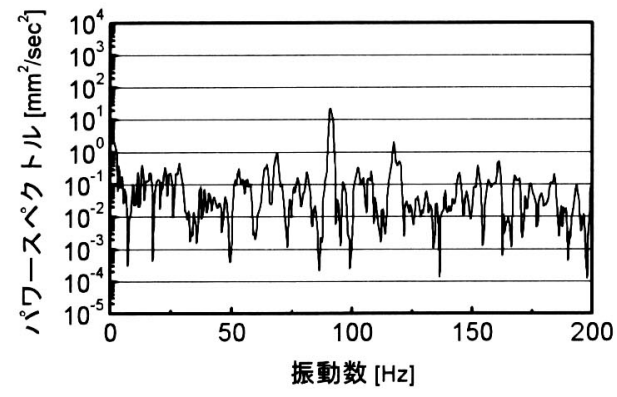

(b) パワースペクトル

図-20 除去することが困難な光学ノイズ

\section{(4) Bootstrap 法による計測精度の評価}

式(6)の平均值の算出に必要な繰り返し計測回数 $N_{A}$ や計測精度の質を定量的に評価するために，同定結果 の不確実性に起因する変動を指標とし, その算出方法 を提案する。これは，同定結果は不確害性に起因して 変動するので，その影響が小さいものは計測精度の質 が高いと判断するものである. 変動の定量化に際して は，振動特性の同定結果は確率変動するとして捉え， 確率分布の信頼区間を算出することと等価であると考 える. 算出の具体的な方法としては, 数值計算を用い たリサンプリング法の一種である Bootstrap 法 ${ }^{14)}$ を適用 する. Bootstrap 法の詳細および同定問題一の適用に関 する詳細は参考文献 15)を参照されたい.

前節のクロススペクトルおよび伝達関数の平均には, 20 回の繰り返し計測を要した。この平均に要する繰り 返し計測回数の妥当性とともに計測精度の質について 検証する. 繰り返し計測回数 $N_{A}$ をパラメータとして, 1 次モードの最大振幅を与える計測点 22 の 99\%信頼区 間を算出する. 図-21 は, 計測回数を 50 まで変化させ た時の 99\%信頼区間の収束性を示すものである. この とき, Bootstrap 標本数と呼ばれるリサンプリング回数 は，それぞれ 2000 回とした. また，通常の同定によっ

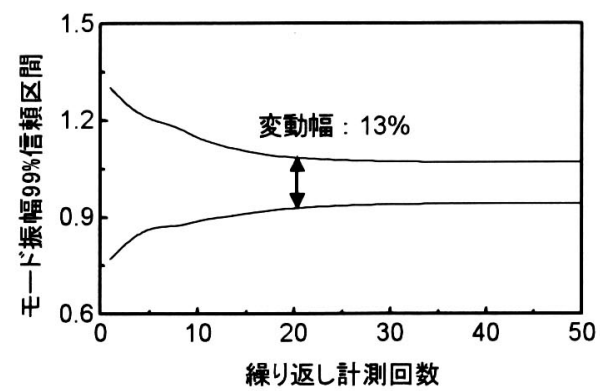

図-21 Bootstrap 法による 99\%信頼区間評価

て得られたモード振幅が 1 となるように正規化を行っ ている. 図より計測回数 20 回付近で信頼区間は収束し ていることが確認できる．したがって，信頼区間の収 束性が必要な繰り返し回数を決定し得る指標のひとつ となるということが言えよう.さらに，信頼区閒の変 動幅を次式の

$$
F R=\frac{T R_{u}-T R_{\ell}}{T R_{m}} \times 100
$$

で定義すると，その信頼区間の変動幅は $13 \%$ であこ 
とがわかる．式中， $T R_{u}, T R_{l}$ およ゙ $T R_{m}$ は信頼区間の 上限值，下限值，平均值である．参考文献 6)における 室内での鋼板の振動モード形に対する同結果では，変 動幅は 5\%であった．したがって，変動幅を指標とする ことで，先述したような改良による計測結果の質を定 量的に評価することが可能となる.

\section{5. まとめと今後の課題}

本研究では，レーザードップラ速度計を用いた非接 触スキャニング振動計測システムに改良を加え，実構 造物に適用し，振動計測結果から部分振動モード形を 同定した。得られた主な成果を以下に述べる.

(1) レーザー戻り光量の最大点を自動探索する機能を 追加することで, 実構造物へのレーザー振動計測の 適用における戻り光量不足という問題を解決した.

（2）鋼部材を対象とした計測精度検証において,レーザ ードップラ速度計と加速度計の振動計測結果は, 時 間・振動数領域ともに高精度で一致した。

(3)構築したレーザー振動計測システムにより, 供用中 の鋼析および RC 床版の振動計測を行い，それをも とに部材固有の振動モード形を同定することが可 能となった．また，計測の質については，Bootstrap 法により定量的に評価した。

今後は, より高次の振動モード形を同定するために, さらに計測精度を向上させる必要がある，そのための 主な改良す心゙き点としては，以下があげられる。

（1）レーザー照射角が大きくなるにつれ，レーザースポ ット径が広がるために, 戻り光量が低下する. そこ で, 現在，手動で調節しているレーザースポット径 の照準設定を計測点ごとに自動化を図る.

(2)人工知能アルゴリズム等を導入し，スペクトル形状 をもとにした光学ノイズの判定手法を構築する.

(3)レーザー戻り光量の自動探索においては, 計測点ご とにノイズレベルの最大点を選定している. 今後, 計測時間の短縮も考慮して, 最低限のノイズレベル を確保するためのしきい值を設定する方法を検討 する.

謝辞 : 本研究は，一部文部省科学研究費および(財) 東 電記念科学技術研究所の助成を受けたものである。 ま た，振動計測に際しては，首都高速道路公団工務部調 査役，宮内博良氏，ならびに株式会社東関東，技術第 二部長赤井公昭氏をはじめ, 多くの方々に御協力を頂 きました。

\section{参考文献}

1) Abe, M.: Structural Monitoring of Civil Structures using Vibration Measurement - Current Practice and Future -, LNAI 1454 Artificial Intelligence in Structural Engineering, pp.1-18, 1998.7.

2) Abe, M., Fujino, Y., Kajimura, T., Yanagihara, M. and Saito, M: Monitoring of a Long Span Suspension Bridge by Ambient Vibration Measurement, Proceedings of The Second Intemational Workshop on Structural Health Monitoring, pp.400-407, Stanford University, Califomia, 1999.9.

3）岩本政巳，阿部雅人：損傷・構造同定, 橋梁振動コロキ ウム'97 論文集，pp.45-54，1997.10

4) Doebling, S.W., Farrar,C.R., Prime, M.B. and Shevitz, D.W.: Damage Identification and Health Monitoring of Structural and Mechanical Systems from Changes in Their Vibration Characteristics : A Literature Review, Los Alamos National Laboratory Report LA-13070-1 IS, 1996.5.

5）貝戸清之，阿部雅人，藤野陽三，依田秀則：レーザードッ プラ速度計を用いた振動モード形の計測と損傷検出への 応用，第 2 回構造物の診断に関するシンポジウム論文集, pp.157-162, 土木学会, 1999.8 .

6）貝戸清之, 阿部雅人, 藤野陽三, 依田秀則 : レーザー常 時微動計測手法の構筑と構造物の損傷検出への応用, 土 木学会論文集, No.689/I-57, pp.183-199, 2001.10

7）金原勲, 影山和郎, 鈴木敏夫, 大沢勇, 伊出浩司：レー ザー振動画像法と有限要素法によるはく離を有する積層 板の振動モ一ド解析，材料，Vol.43，No.487, pp.476-481， 1994.4 .

8) Meza, R., Carrasco, C.J., Osegueda, R.A, James, G and Robinson, N.: Damage Detection in a DC-9 Fuselarge using Laser Doppler Velocimetry, Proceedings of the 15th Intemational Modal Analysis Conference, pp.1779-1785, Orlando, 1997.2.

9）長松昭男：モード解析入門，コロナ社, 1993.7.

10）貝戸清之: 不確定性を考虑したレーザー振動計測に基づく 構造物の性能評価，東京大学博士論文，2000.3.

11) Kaito, K., Abe, M., Fujino, Y. and Yoda, H.: Detection of Structural Damage by Ambient Vibration Measurement using Laser Doppler Vibrometer, Proceedings of The 5th Intermational Symposium on Non-Destructive Testing in Civil Engineering 2000, pp.137-143, Tokyo, 2000.4

12) Kaito, K., Abe, M. and Fujino, Y.: Identification of Vibration Mode Shapes for a Bridge Deck under Ambient Vibration, Proceedings of 6th Intermational Workshop on Material Properties and Design, Proceedings of The Present and Future in Health Monitoring, pp.347-358, Bauhaus-University, Weimar, Germany, 2000.9.

13）貝戸清之，阿部雅人，藤野陽三，本村均，金子謙一郎： 
レーザー常時微動計測に基づく RC 床版の振動モード形の 同定, 土木学会第 55 回年次学術講演会講演概要集, 共通 セッション, CS-75, 2000.9 .

14) Efron, B. and Tibshirani, R.: An Introduction to the Bootstrap, Chapman and Hall, 1993.
15）貝戸清之, 阿部雅人, 藤野陽三 : 不確実性に起因する振 動特性変化の定量化とその有意性検定手法の提案, 土木 学会論文集, No.682/1-56, pp.399-414, 2001.7.

\title{
DEVELOPMENT OF NON-CONTACT SCANNING VIBRATION MEASUREMENT SYSTEM WITH LASER DOPPLER VIBROMETER FOR EXISTING STRUCTURES
}

\author{
Kiyoyuki KAITO, Masato ABE, Yozo FUJINO and Hitoshi MOTOMURA
}

In order to rationalize structural maintenance, a non-contact vibration measurement system with Laser Doppler Vibrometer (LDV) has been constructed in laboratory testing. However, in the case of measuring vibration of existing real structures, the objectives would possess low laser reflection characteristics. Therefore, it is difficult to apply an LDV to these. In this study, the measurement system is improved with an automatic searching function of the optical point that could give the maximum laser reflection around the objective points. This improvement produces a tremendous advance in measurement accuracy for real structures. As a case study, vibration measurement is conducted at a steel girder and a reinforced concrete of existing viaduct. The mode shapes are identified and quality of measurement is also evaluated quantitatively. 